Available online at GSC Online Press Directory

GSC Biological and Pharmaceutical Sciences

e-ISSN: 2581-3250, CODEN (USA): GBPSC2

(RESEARCH ARTICLE)

\title{
Bioremediation potentials of chicken droppings on crude oil polluted soil from automobile workshop
}

\author{
Makut Danladi Makwin and Majekodunmi Olasumbo Opemipo * \\ Department of Microbiology, Nasarawa State University, P.M.B. 2022, Keffi, Nigeria.
}

Publication history: Received on 6 July 2019; revised on 08 August 2019; accepted on 13 August 2019

Article DOI: https://doi.org/10.30574/gscbps.2019.8.2.0138

\begin{abstract}
The bioremediation properties of chicken droppings on crude oil contaminated soil from automobile workshop in Keffi Nasarawa State of Nigeria were evaluated. Two experimental treatment (T1 and T2) with 10\% and 30\% chicken dropping addition to the contaminated soil were set up. A control (T3) was also set up consisting of contaminated soil only. The set up design was left for a period of 4 weeks during which the total heterotrophic bacteria (THB) count, total petroleum hydrocarbon degraded and gas chromatography and mass spectroscopy (GCMS) identification of the residue hydrocarbon after remediation were carried out. Soil samples remediated with $30 \%$ CD had significantly $(p<0.05)$ the highest THB in the range of $6.45 \times 10^{7}-11.23 \times 10^{7}$ when compared with those remediated with $10 \%$ CD $\left(5.34 \times 10^{7}-\right.$ $8.36 \times 10^{7}$ ). The non-remediated control had the least THB count of $3.45 \times 10^{7} \mathrm{CFU} / \mathrm{g}$. There was a rapid and progressive reduction in the total petroleum hydrocarbon during remediation in all the soil bio-remediated with $30 \%$ chicken droppings compared to that of un-remediated soil. Automobile contaminated soil from Anguwan Kwara are more susceptible to remediation had the highest TPH degraded of 22, 39, 44 and $57.04 \%$, at the end of the days 7, 14, 21 and 28 days respectively. GCMS revealed a total of 12,14,8,9 and 17 residual hydrocarbons in soil samples from Keffi Garage, New Keffi Hotel, Angwan Kwara, High Court and Angwan Tanko automobile workshops respectively after remediation with $30 \%$ chicken droppings while non-remediated soil recorded 22 residual hydrocarbons. The research shows that chicken droppings enhanced bioremediation of crude oil contaminated soil from automobile workshops.
\end{abstract}

Keywords: Automobile workshops; Bioremediation; Chicken droppings; Total heterotrophic bacteria.

\section{Introduction}

Soil contamination and its adverse effect on the overall ecosystem is one of the major problems we are facing today (1). The global increase in the use of petroleum and its products has led to severe contamination of soil and ground water. Large number and size of areas in most developed and developing countries like Nigeria are contaminated with crude oil via naturally process (natural oil seeps) or anthropogenic as in the case of accidental or deliberate spills and leakages such as intentional or accidental bursting of pipelines (2). Indeed, the negative effects of pollutants in the environment and on human health are diverse and depend on the nature of the pollution, thus, control and treatment strategies to combat the hazardous effects of oil pollution are needed.

Conventional physical and chemical treatment methods have high costs and can generate residues that are toxic to the biota (3). Consequently, there is need for innovation methods to restore these polluted sites especially in an inexpensive, environmentally friendly manner. Among the many unique methods employed to clean up oil polluted sites, bioremediation is the most widely used (4).

\footnotetext{
${ }^{*}$ Corresponding author

E-mail address: majekodunmiopemipo@gmail.com
} 
Economical strategies for bioremediation include natural attenuation, biostimulation, bioventing, bioaugmentation, composting, and phytoremediation (5). Crude oil bioremediation can be supported by increasing the indigenous microorganisms, through introduce nutrients into the ecosystem (biostimulation) or addition of microbial consortium (bioaugmentation) as highlighted in several bioremediation reports (6-7).

Bioremediation refers to the use of naturally occurring microorganisms by man to detoxify man-made pollutants (8). Since bioremediation is a microbial process, it requires the provision of nutrients among other factors or requirements. The addition of organic waste materials to the soil facilitates aeration through small pores and increases the water holding capacity of the soil, thus enhancing bioremediation (9).

Among the various organic waste, chicken droppings are considered a more valuable resource which when managed properly, can reduce the need for commercial fertilizer. Organic nutrients such as chicken droppings when added to polluted sites act both as source of nutrients and of microorganisms. Ijah and Antai, (4) reported that chicken droppings habour bacteria and fungi that can utilize crude oil efficiently. Chemical analysis of chicken droppings and cow dung showed that they contain high percentage of nitrogen, phosphorous, potassium and sodium salts which can enhancing bioremediation (10). Therefore, the aims of this study is to determine the effectiveness of chicken droppings in the remediation of oil polluted soil from automobile workshop in Keffi, Nassarawa State, Nigeria.

\section{Material and methods}

\subsection{Sample collection}

Oil contaminated soil was collected from 5 different automechanic workshops at Keffi garage, Opposite New Keffi hotel, Angwan Kwara, High court, and Angwan Tanko, all in Keffi, Nasarawa State Nigeria. At each sampling point, two samples were collected at a depth of $10 \mathrm{~cm}$ and bulk samples were collected in polythene bags and immediately transported to the laboratory for analysis. The soil amendment material (poultry droppings) was collected from Lawal Poultry Farms, Pyanku, Nasarawa State, Nigeria.

\subsection{Soil amendment and bioremediation}

Bioremediation study was carried out according to the method described by Okafor et al. (10). Two experimental treatment (T1 and T2) and a control treatment (T3) was set up as shown in the table below. The set-up design was left for a period of 4 weeks

Table 1 Experimental set up for bioremediation

\begin{tabular}{lll}
\hline & Experimental groups & Description \\
\hline T1 & Chicken dropping added at 10\% & 80 g of polluted soil + 8g of chicken droppings \\
T2 & Chicken dropping added at 30\% & 80 g of polluted soil + 24g of chicken droppings \\
T3 & Control & 80 g of polluted soil only (control) \\
\hline
\end{tabular}

\subsection{Total heterotrophic bacteria (THB) count}

Total heterotrophic bacteria counts in the soil was determined by plating a serially diluted $1 \mathrm{~g}$ of the soil on oil agar (OA) [1.8 $\mathrm{g} \mathrm{K}_{2} \mathrm{HPO}_{4}, 4.0 \mathrm{~g} \mathrm{NH}_{4} \mathrm{Cl}, 0.2 \mathrm{~g} \mathrm{MgSO}_{4} 7 \mathrm{H}_{2} \mathrm{O}, 1.2 \mathrm{~g} \mathrm{KH}_{2} \mathrm{PO}_{4}, 0.01 \mathrm{~g} \mathrm{FeSO}_{4} 7 \mathrm{H}_{2} \mathrm{O}, 0.1 \mathrm{~g} \mathrm{NaCl}, 20 \mathrm{~g}$ agar, $1 \%$ (v/v) used lubricating oil in $1000 \mathrm{~mL}$ distilled water, $\mathrm{pH} 7.4$ (11), and incubated at $30^{\circ} \mathrm{C}$ for $72 \mathrm{~h}$. The colonies on each plate were counted and recorded as colony forming unit per gram of soil (CFU/g).

\subsection{Total petroleum hydrocarbon (TPH) degradation}

Total petroleum hydrocarbon content of the soil samples was determined using Gas Chromatographic methods according to the toluene extraction method (11) and Sonication water bath methods. Fifteen grams (15g) of each of the sample was weighed into $50 \mathrm{ml}$ conical flasks, and then $1 \mathrm{ml}$ of $60 \mathrm{ug} / \mathrm{ml}$ of 1 -chlorooctadecane surrogate standard was added. Then 30 milliliters of dichloromethane (extraction solvent) was added to extract oil in the soil. After shaking vigorously in water bath for $5 \mathrm{hrs}$, the mixture was allowed to stand for 60 minutes and then filtered through Whatman No.1 filter paper fitted with cotton wool and sodium sulphate into a clean beaker washed with methylene chloride. The 
residue was then washed with $20 \mathrm{ml}$ extracting solvent and then filtered through funnel. The extracted oil was transferred to vial and placed on a gas chromatographic chamber for analysis. The amount of waste lubricating oil degraded was calculated by subtracting the weight of residual waste lubricating oil from weight of the initial waste lubricating oil, divided by the weight of the initial waste lubricating oil and then multiplied by 100 .

$$
\mathrm{HR}(\%)=\frac{(\mathrm{Wt} \text { of oil before remediation })-(\mathrm{Wt} \text { of oil after remediation }}{\text { Wt of oil before remediation }} \times 100
$$

\subsection{Extraction of oil for GC-MS analysis}

The oil was extracted by solvent extraction using dichloromethane (DCM). Soil sample $(20 \mathrm{~g})$ was extracted with $20 \mathrm{ml}$ of DCM and the extract was evaporated to dryness. The dry residue was re-dissolve in $20 \mathrm{ml}$ of DCM then evaporated to dryness. The final residue was re-dissolved in $5 \mathrm{ml}$ of DCM and analyzed by GC and chromatograms were obtained (1214).

\section{Results}

\subsection{Total heterotrophic bacteria (THB) count}

The total heterotrophic bacteria (THB) count in all experimental soil after four (4) weeks of bioremediation with chicken droppings are presented in figure 1: All the bio-remediated soil had significantly $(\mathrm{p}<0.05)$ higher THB than the control (un-remediated) soil. In all the soil samples remediated $30 \%$ remediation had significantly $(p<0.05)$ the highest THB in the range of $6.45 \times 10^{7}-11.23 \times 10^{7}$ when compared with those remediated with $10 \%$ chicken droppings $\left(5.34 \times 10^{7}\right.$ $8.36 \times 10^{7}$ ). The non-remediated control had the least THB count of $3.45 \times 10^{7} \mathrm{CFU} / \mathrm{g}$. soil sample collected from Anguwan Kwara automobile workshop had the highest THB $\left(11.23 \times 10^{7} \mathrm{CFU} / \mathrm{g}\right)$ when compared with soil sample from other location.

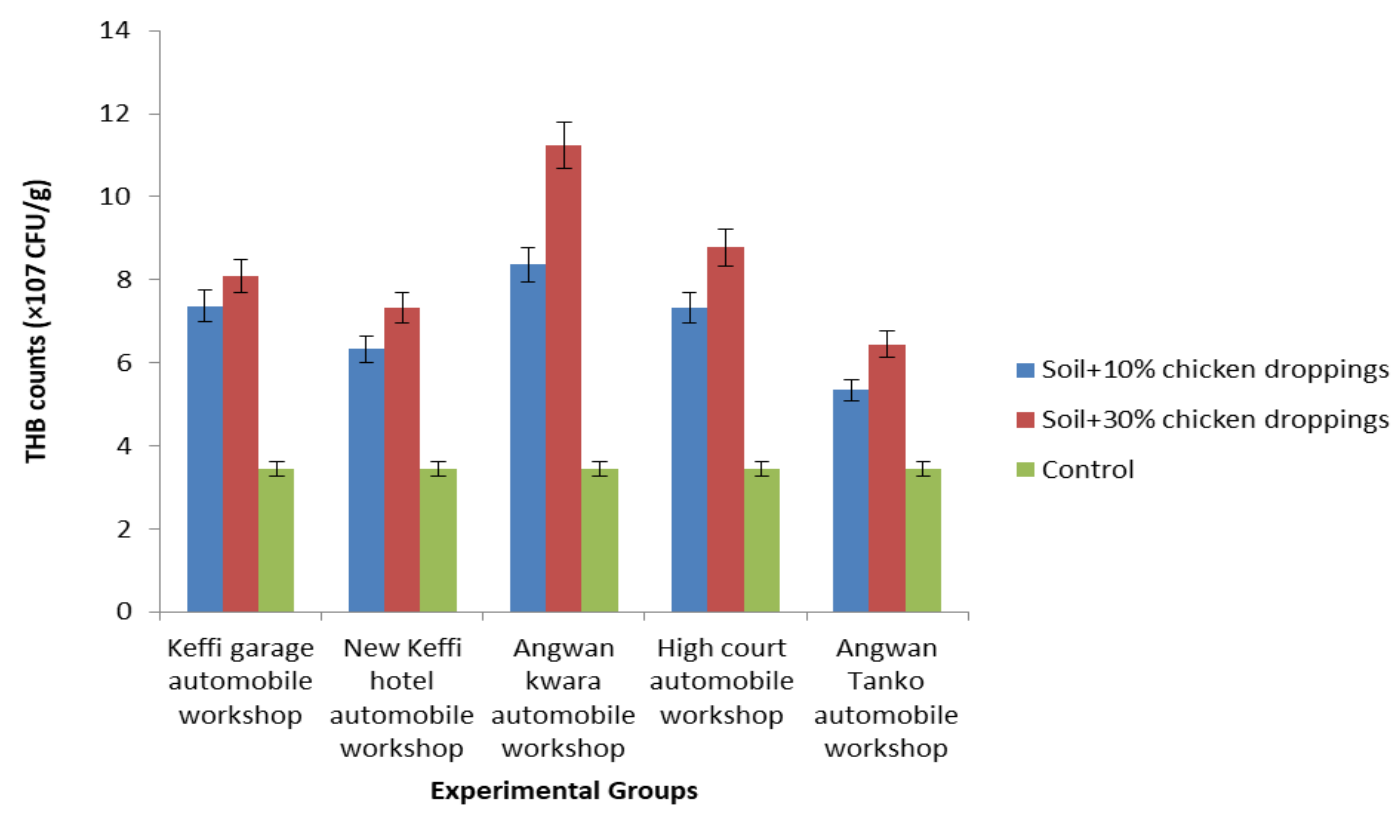

Figure 1 Total heterotrophic bacteria (THB) count in contaminated soil during bioremediation

\subsection{Biodegradation of used oil}

The level of biodegradation of automobile oil in the soil sample throughout the study period is shown in figure 2. There was a rapid and progressive reduction in the total petroleum hydrocarbon during remediation in all the soil bioremediated with $30 \%$ chicken droppings compared to that of un-remediated soil. Automobile contaminated soil from Anguwan Kwara are more susceptible to remediation had the highest TPH degraded of 22, 39, 44 and 57.04 \%, at the end of the days $7,14,21$ and 28 days respectively. 


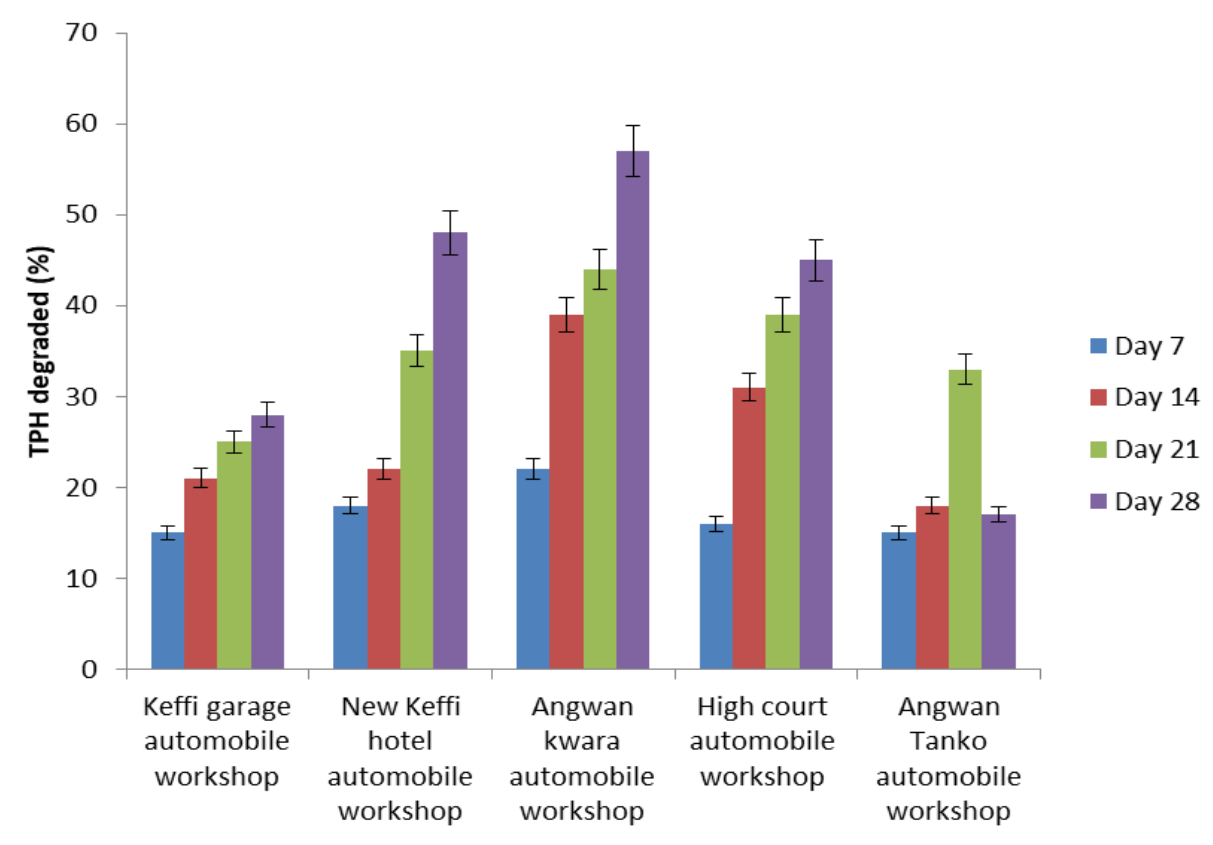

Figure 2 Total petroleum hydrocarbon degraded from oil contaminated soil during bioremediation

\subsection{Gas Chromatography and Mass spectroscopy}

Gcms analysis revealed significant reduction in number of individual hydrocarbons with bioremediation. A total of 12 , 14, 8, 9 and 17 individual hydrocarbons were recorded in soil samples from keffi garage automobile workshop, new keffi hotel automobile workshop, angwan kwara automobile workshop, high court automobile workshops and angwan tanko automobile workshops respectively after remediation with 30\% chicken droppings. However, a total of 22 individual hydrocarbons were obtained in non-remediated control soil.

Table 2 Hydrocarbon identified in bio-remediated soil from keffi garage automobile workshop

\begin{tabular}{llcl}
\hline PK & RT & Retention Area (\%) & COMPOUNDS \\
\hline 1 & 9.741 & 0.98 & Dodecane, 4,6-dimethyl- \\
2 & 10.062 & 1.08 & Naphthalene, 2-methyl- \\
4 & 11.126 & 3.60 & Decahydro-1,1,4a,5,6-pentamethylna phthalene \\
5 & 11.246 & 1.63 & Dodecane, 2,6,11-trimethyl- \\
6 & 11.635 & 6.50 & Tetradecane \\
7 & 11.910 & 8.67 & Naphthalene, 2,6-dimethyl- \\
8 & 12.105 & 0.97 & Naphthalene, 2,7-dimethyl- \\
9 & 12.242 & 2.94 & 6-Octen-1-ol, 3,7-dimethyl-, (R)- \\
10 & 12.362 & 3.34 & Decahydro-1,1,4a,5,6-pentamethylna phthalene \\
11 & 12.436 & 6.46 & Dodecane, 2,6,11-trimethyl- \\
16 & 13.598 & 1.80 & Naphthalene, 1,6,7-trimethyl- \\
17 & 13.741 & 3.13 & 4,6,8-Trimethylazulene \\
\hline
\end{tabular}


Table 3 Hydrocarbon identified in bio-remediated soil from new keffi hotel automobile workshop

\begin{tabular}{llcl}
\hline PK & RT & Retention Area (\%) & COMPOUNDS \\
\hline 1 & 11.103 & 4.01 & Decahydro-1,1,4a,5,6-pentamethylna phthalene \\
2 & 11.624 & 6.72 & Tetradecane \\
3 & 11.870 & 8.59 & Naphthalene, 1,6-dimethyl- \\
4 & 12.213 & 3.68 & Citronellol \\
5 & 12.339 & 4.29 & Decahydro-1,1,4a,5,6-pentamethylna phthalene \\
6 & 12.414 & 5.64 & Undecane \\
8 & 13.306 & 2.43 & Naphthalene, 1,4,6-trimethyl- \\
12 & 14.187 & 5.15 & Hexadecane \\
13 & 14.731 & 3.74 & Hentriacontane \\
14 & 15.400 & 4.81 & Dodecane, 2-methyl-8-propyl- \\
15 & 15.458 & 2.76 & Dodecane, 2,6,11-trimethyl- \\
17 & 16.562 & 2.30 & $2,6,10$-Trimethyltridecane \\
22 & 21.283 & 3.33 & Tricosane \\
26 & 24.464 & 1.14 & Tetracosane \\
\hline
\end{tabular}

Table 4 Hydrocarbon identified in bio-remediated soil from angwan kwara automobile workshop

\begin{tabular}{llcl}
\hline PK & RT & Retention Area (\%) & COMPOUNDS \\
\hline 1 & 15.338 & 1.04 & 1-Heptadecanamine \\
2 & 17.432 & 0.69 & 1-Octanol, 2-butyl- \\
6 & 21.174 & 2.09 & Octatriacontyl pentafluoropropionate \\
7 & 23.663 & 4.65 & Tetrapentacontane, 1,54-dibromo- \\
8 & 24.430 & 11.22 & Carbonic acid, eicosyl vinyl ester \\
9 & 25.168 & 10.06 & Octacosane \\
13 & 27.886 & 8.20 & Tritetracontane \\
18 & 30.958 & 0.92 & Octadecane \\
\hline
\end{tabular}

Table 5 Hydrocarbon identified in bio-remediated soil from high court automobile workshops

\begin{tabular}{llll}
\hline PK & RT & Retention Area (\%) & COMPOUNDS \\
\hline 1 & 14.073 & 8.91 & Hexadecane \\
2 & 14.634 & 3.38 & Pentadecane, 2,6,10-trimethyl- \\
3 & 15.234 & 5.09 & Heptadecane \\
4 & 15.28 & 10.44 & Hexadecane, 2,6,10,14-tetramethyl \\
5 & 16.35 & 8.47 & Octadecane \\
6 & 16.430 & 7.21 & Methoxyacetic acid, 2-tridecyl ester \\
7 & 17.415 & 7.66 & Nonadecane \\
8 & 18.427 & 11.33 & Eicosane \\
9 & 19.394 & 8.78 & Heneicosane \\
\hline
\end{tabular}


Table 6 Hydrocarbon identified in control non bioremediated oil contaminated soil

\begin{tabular}{|c|c|c|c|}
\hline PK & RT & Area\% & Compounds \\
\hline 1 & 9.747 & 1.38 & Dodecane, 4,6-dimethyl \\
\hline 2 & 10.068 & 2.52 & Naphthalene, 1-methyl- \\
\hline 3 & 10.171 & 3.22 & Tridecane \\
\hline 4 & 11.109 & 3.12 & Decahydro-1,1,4a,5,6-pentamethylnaphthalene \\
\hline 5 & 11.241 & 0.89 & Dodecane, 2,6,11-trimethyl \\
\hline 6 & 11.624 & 7.94 & Tetradecane \\
\hline 7 & 11.904 & 10.99 & Naphthalene, 2,7-dimethyl- \\
\hline 8 & 12.219 & 2.07 & Cyclohexane, 1-(cyclohexylmethyl)- 2-ethyl-, trans- \\
\hline 9 & 12.345 & 2.74 & Decahydro-1,1,4a,5,6-pentamethylna phthalene \\
\hline 10 & 12.425 & 6.13 & Carbonic acid, eicosyl vinyl ester \\
\hline 11 & 12.963 & 1.83 & Dodecane \\
\hline 12 & 13.558 & 1.83 & Naphthalene, 2,3,6-trimethyl- \\
\hline 13 & 15.56 & 5.71 & Decane, 2-methyl- \\
\hline 14 & 15.612 & 3.31 & Dodecane, 2,6,11-trimethyl- \\
\hline 15 & 16.711 & 5.10 & 2,6,10-Trimethyltridecane \\
\hline 16 & 19.623 & 5.22 & Heneicosane \\
\hline 17 & 20.527 & 5.43 & Docosane \\
\hline 18 & 21.386 & 5.78 & Tricosane \\
\hline 19 & 22.221 & 6.64 & Tetracosane \\
\hline 20 & 23.011 & 5.88 & Pentacosane \\
\hline 21 & 23.766 & 4.35 & Hexadecane, 1-iodo- \\
\hline 22 & 25.219 & 1.65 & Octacosane \\
\hline
\end{tabular}

\section{Discussion}

The increasing industrial development promotes serious environmental damage due to pollution of the environment. Bioremediation is the use of naturally occurring microorganisms or genetically engineered microorganisms by man to detoxify man-made pollutants [15]. In the present study, there was a rapid and progressive reduction in the total petroleum hydrocarbon during remediation in all the soil bio-remediated with chicken droppings compared to that of un-remediated soil sample. Although microorganisms are present in contaminated soil, their numbers might not be sufficient to initiate remediation of contaminated sites [16]. The growth and activities of THB must be stimulated and all require nitrogen, phosphorus, and carbon as building blocks. There was a rapid and progressive reduction in the total petroleum hydrocarbon during remediation in all the soil bio-remediated with $30 \%$ chicken droppings compared to that of un-remediated soil. This study shows that the contaminated soil from Anguwan Kwara remediated with $30 \%$ chicken droppings had the highest TPH degraded of $57.04 \%$ at the end of remediation (day 28). This may be due to the high nutrient availability from the soil samples in this location and poultry droppings resulting in high percentage of nutrient ( $\mathrm{N}$ and $\mathrm{C}$ ) which are needed for optimum growth and performances of HUB thus facilitating the synthesize of the necessary enzymes needed to break down the petroleum hydrocarbon contaminants [17-19]. This observation is in agreement with previous studies by Ibiene et al., [20] who reported $97.83 \%$ \& 98.21\%, percentages of TPH loss in the cow dung \& poultry droppings remediated hydrocarbon contaminated soil in Niger Delta and implicated Bacillus, Pseudomonas, Kebsiella, Proteus, Flavobacterium, Clostridium, Micrococcus, Acinetobacter, Penicillium, Aspergillus, Sacharomyces, Rhizopus, Fusarium and Mucor as the hydrocarbon utilizing organisms from the study area. Adeleke et al., [21] also compare the potentials of activated soil and activated cow dung in bioremediation of three agricultural soil samples of Igodan - Lisa, Oba-Ile and Idoani in Ondo State, Nigeria, the author documented that the activated cow dung 
exhibited higher percentage (52.12 - 60.23\%) of crude oil loss than activated soil (39.84 - 44.16\%) at both 5 and $10 \%$ levels of activated materials addition.

Gas chromatography (GC) coupled with mass spectrometry (MS) are the methods used for identification of compounds in crude oil. In this study, gas chromatography with mass spectrometer were used to provide insight into the hydrocarbon composition of diesel contaminated soil after bioremediation. GC-MS chromatogram show significant hydrocarbon degradation in all sample tested compared to non-remediated control. The chromatograms of the bioremediated soil revealed some peaks. When the mass spectra of the constituents from these samples were compared with the NIST library, a total of 14, 15, 8, 12, and 17 individual hydrocarbons were recorded in soil samples from Keffi Garage automobile workshop, new Keffi Hotel automobile workshop, Angwan Kwara automobile workshop, high court automobile workshops and Angwan Tanko automobile workshops respectively after remediation with $30 \%$ chicken droppings. However, a total of 22 individual hydrocarbons were obtained in non-remediated control soil. The trend of this results correlates with TPH degraded.

Amendment of crude oil contaminated soils with chicken droppings has the potential to be an effective, relatively novel strategy to mitigate the risk of organic compound contamination and exposure in soils. By implications, the bioremediation technique proposed here for automobile workshop soils polluted with crude oil could be suitable in field, because of its low costs and its low environmental risk associated with volatile hydrocarbon losses.

\section{Conclusion}

In the present study, chicken droppings increased the bioremediation of crude oil contaminated soil from automobile workshop, which implies that microbial degradation of crude oil has been enhanced. This enhancement could probably be due to the mineral nutrients and the crude oil degrading microorganisms present in the chicken droppings.

\section{Compliance with ethical standards}

\section{Acknowledgments}

The authors would like to acknowledge the technical staff of Department of Microbiology, Nasarawa State University, Keffi, Nigeria.

\section{Disclosure of conflict of interest}

No conflict of interest exists.

\section{References}

[1] Ijah UJJ, Auta SH and Olanrewaju RK. (2013). Biostimulation of crude oil contaminated soil using soybean waste. Advanced Science Focus, 1, 1-7.

[2] Nnadi PC and Osakwe JA. (2017). Bioremediation of crude oil contamination soil with livestock waste. International Journal of Agriculture and Earth Science, 3(7).

[3] Okafor UC, Michael UO, Kingsley CA, Nsikak SA, Benjamin CO, Onyedika IO and Okoro NCN. (2016). Bioremediation of crude oil-polluted soil using broiler-chicken droppings. Journal of Applied \& Environmental Microbiology, 4(4), 75-84.

[4] Ijah UJ and Antai SP. (2003). The Potential use of chicken droppings microorganisms for oil spill remediation. The Environmentalist, 23, 89-95.

[5] Bento FM, Camargo FAO, Okeke B and Frankenberger WT. (2005). Comparative bioremediation of soils contaminated with diesel oil by natural attenuation, biostimulation and bioaugmentation. Bioresource Technology, 96(9), 1049-1055.

[6] Qiao J, Zhang Ch, Luo Sh and Chen W. (2014). Bioremediation of highly contaminated oilfield soil: Bioaugmentation for enhancing aromatic compounds removal. Frontiers of Environmental Science \& Engineering, 8 (2), 293-304.

[7] Mohajeri L, Aziz HA, Isa MH, Zahed MA and Mohajeri S. (2013). Effect of remediation strategy on crude oil biodegradation kinetics and half-life times in shoreline sediment samples. Int. J. Mar. Sci. Eng., 3(2), 99-104. 
[8] Andreolli M, Lampis S, Brignoli P and Vallini G. (2015). Bioaugmentation and biostimulation as strategies for the bioremediation of a burned woodland soil contaminated by toxic hydrocarbons: A comparative study. J. Environ. Manage, 153, 121-131.

[9] Chikere CB, Chikere BO and Okpokwasili GC. (2012). Bioreactor-based bioremediation of hydrocarbon-polluted Niger Delta marine sediment, Nigeria J. Biotechnology, 2(53), 66.

[10] Okafor UC and Orji MU. (2016). Effects of chicken droppings amendment on bioremediation of crude oil polluted soil. European Journal of Experimental Biology, 6, 62-68.

[11] Nwankwegu AS, Onwosi CO, Orji MU, Anaukwu CG, Okafor UC, Azi F and Martins PEJ. (2016). Effect of chicken droppings ammendment on bioremediation of crude oil polluted soil. Environmental Management, 172, 136 142 .

[12] Lawal B, Shittu OK, AbdulRasheed-Adeleke T, Ossai PC, and Ibrahim AM. (2015). GC-MS Determination of bioactive constituents of giant African snail (Archachatina maginata) Haemolymph. IOSR Journal of Pharmacy and Biological Sciences (IOSR-JPBS), 10(2), 59-64.

[13] Ibrahim AM, Lawal B, Tsado NA, Yusuf AA and Jimoh AM. (2015). Phytochemical Screening and GC-MS determination of bioactive constituents from methanol leaf extract of Senna occidentalis. . Journal of Coastal Life Medicine, 3(12), 992-995.

[14] Lawal B, Shittu OK, Abubakar AN, Olalekan IZ, Jimoh AM and Abdulazeez AK. (2015). Drug leads agents from methanol extract of Nigerian bee (Apis mellifera) Propolis. J. Intercult Ethnopharmacology, 5(1), 43-48.

[15] Umar H, Umar A, Ujah UJ, Hauwa B, Sumayya BI, Shuaibu M and Yakubu MS. (2013). Biodegradation of waste lubricating oil by bacteria isolated from the soil. Journal of Environmental Science, Toxicology and Food Technology, 3(6), 62-67.

[16] Nwogu TP, Azubuike CC and Ogugbue CJ. (2015). Enhanced bioremediation of soil artificially contaminated with petroleum hydrocarbons after amendment with Capra aegagrus hircus (Goat) Manure.

[17] Vidali M. (2001). Bioremediation. An overview. Pure and Applied Chemistry, 73(7), 1163-1172.

[18] Al-Mailem DM, Sorkhoh NA, Al-Awadhi H, Eliyas M and Radwan SS. (2010). Biodegradation of crude oil and pure hydrocarbons by extreme halophilic archaea from hypersaline coasts of the Arabian Gulf. Extremophiles, 14(3), 321-328.

[19] Kang JW. (2014). Removing environmental organic pollutants with bioremediation and phytoremediation. Biotechnol Lett, 36(6), 1129-1139.

[20] Ibiene AA, Orji FA, Ezidi CO and Ngwobia CL. (2011). Bioremediation of hydrocarbon contaminated soil in the niger delta using spent mushroom compost and other organic wastes. Nigerian Journal of Agriculture, Food and Environment, 7(3), 1-7.

[21] Adeleke IF, Esther BB and Clement AF. (2016). The microbiological and physicochemical properties of some crude oil contaminated and uncontaminated agricultural soils in Ondo State, Nigeria. Pyrex Journal of Microbiology and Biotechnology Research (PJMBR), 2(1), 1-8.

\section{How to cite this article}

Makut DM and Majekodunmi 00. (2019). Bioremediation potentials of chicken droppings on crude oil polluted soil from automobile workshop. GSC Biological and Pharmaceutical Sciences, 8(2), 45-52. 